\title{
EDITORIAL \\ Food and Drug Administration Safety Communication on rhBMP-2 use
}

\author{
John R. W. Kestle, MD \\ Division of Pediatric Neurosurgery, University of Utah, Salt Lake City, Utah
}

$\mathrm{T}$

HE use of recombinant human bone morphogenetic protein-2 (rhBMP-2) in pediatric spinal surgery is discussed in the paper by Sayama et al. ${ }^{2}$ Fifty-seven children, aged 9 months to 20 years (mean 11 years, 4 months), having posterior fusion at various spinal levels also received rhBMP-2 between 2007 and 2011. The goal of the retrospective review is to assess the risk of developing cancer in these patients. This risk had been reported in the adult literature. In this pediatric series, no new cases of cancer or degeneration or metastasis of existing malignancies were identified.

The authors recognize and do their best to address a number of limitations of their data:

1. They did not perform any form of cancer screening. Based on a review by the head of neuro-oncology, screening would have had a very low yield and was therefore felt not to be worthwhile.

2. Their follow-up was a minimum of 2 years. Although this is very good from the perspective of spinal fusion, this time frame is short for the development of de novo cancer. The authors acknowledge this and plan to follow their participants much longer.

3. There were 7 missing patients. The authors made repeated attempts to contact these patients by multiple modalities, and they searched online for their names. They identified one of the patients who had died in this way.

4. Sources of error in estimating the event rate. The authors correctly acknowledge that a confidence interval can be calculated on a rate of zero, and they did this. In addition, they did a sensitivity analysis assuming that none of the missing patients developed cancer and then assuming that all of the missing patients developed cancer. This resulted in a worse-case scenario incidence of cancer of $24 \%$.
5. They had explicit discussion with patients' families regarding the use of rhBMP-2 in an off-label fashion.

In the Discussion, there is a nice description of the adverse events that have been reported with rhBMP-2. None of these events are described in the authors' series of cases explicitly, and the reader is left to assume that none occurred.

The authors are not alone in their use of rhBMP-2. In a report from their same institution (Lam et al.), based on the KIDS' inpatient database, there were 9538 hospitalizations in patients 20 years old and younger for spinal fusion in 2009. ${ }^{1}$ Of these admissions, 1541 were associated with rhBMP-2 use.

The cautious tone of the discussion in the current paper is appropriate. ${ }^{2}$ On January 21, 2015, the FDA distributed a Safety Communication regarding the use of recombinant proteins and synthetic peptides that are used to promote new bone growth or to replace or heal existing bone. ${ }^{3}$ These are approved for use only in patients over the age of 18 years. The communication reminds the medical community that these products are not approved for any patients under the age of 18 , who are still skeletally immature and growing. They recommend that providers consider other options before using substitutes containing recombinant proteins or synthetic peptides. They acknowledge that patients under 18 years of age, with significant bone defects or rare bone disorders, may have limited treatment options, but they recommend that we consider the benefits and risks before using these products in any patient. If such a product is considered the best or only option, they remind us to inform parents/guardians and patients about the risks and benefits of using the product when discussing surgical options. If these products are used, patients should be closely monitored for adverse events, which may include problems with skeletal devel- 
opment, excess growth of other tissues, and tissue swelling or fluid accumulation that could put pressure on adjacent organs or tissues.

Clearly we should proceed with caution with these products until further safety evidence if available.

http://thejns.org/doi/abs/10.3171/2015.2.PEDS15112

\section{References}

1. Lam SK, Sayama C, Harris DA, Briceño V, Luerssen TG, Jea A: Nationwide practice patterns in the use of recombinant human bone morphogenetic protein-2 in pediatric spine surgery as a function of patient-, hospital-, and procedurerelated factors. J Neurosurg Pediatr 14:476-485, 2014

2. Sayama C, Willsey M, Chintagumpala M, Brayton A, Briceño V, Ryan SL, et al: Routine use of recombinant human bone morphogenetic protein-2 in posterior fusions of the pediatric spine and incidence of cancer. $\mathbf{J}$ Neurosurg Pediatr [epub ahead of print April 10, 2015. DOI: 10.3171/2014.10. PEDS14199]

3. US Food and Drug Administration: Use of Bone Graft Substitutes Containing Recombinant Proteins or Synthetic Peptides in Patients under Age 18 - FDA Safety Communication. (http://www.fda.gov/MedicalDevices/Safety/Alerts andNotices/ucm430868.htm?source=govdelivery\&utm medium=email\&utm_source=govdelivery) [Accessed March $16,2015]$

\section{Response}

\section{Andrew Jea, MD, ${ }^{1}$ Christina Sayama, MD, MPH, ${ }^{2}$ and Thomas G. Luerssen, MD'}

'Division of Pediatric Neurosurgery, Texas Children's Hospital, Houston, Texas; and 'Division of Pediatric Neurosurgery, Doernbecher Children's Hospital, Portland, Oregon

We thank Dr. Kestle for his reflective comments about our study examining the use of rhBMP-2 in children and the nil incidence of cancer in our limited series. We agree with Dr. Kestle's analysis of the weaknesses of our study and his interpretation of the cautious tone struck in the conclusions of our study regarding BMP use. Most significantly (and appropriately), however, Dr. Kestle highlights in a very timely manner the most recent FDA Safety Communication on BMP use in children. ${ }^{9}$

There are a few points regarding the FDA and its Safety Communication that we would like to emphasize ourselves:

1. The most recent FDA Safety Communication does not contain any new information or warnings that were not already present in the original FDA-approved indications and contraindications for BMP in 2002. ${ }^{8}$ It is unclear why this Safety Communication was re-released at this time.

2. It is interesting to note that the most recent FDA Safety Communication makes no mention of cancer as a potential risk of BMP use in patients less than 18 years of age. Perhaps this reflects new evidence, in addition to the tenuous results in our own study, that there is no increased risk of cancer with BMP use. ${ }^{10,11}$

3. The Safety Communication's citation that BMP should not be used in "skeletally immature" patients because it causes premature fusion is altogether illogical. This would imply that all spinal fusion procedures in this patient population, whether performed in conjunction with BMP use or not, are contraindicated.

4. The Safety Communication cites that BMP was not evaluated for safety and effectiveness in patients less than 18 years of age. However, in general, the FDA infrequently approves drugs and medical devices with pediatric-specific indications. Companies have no financial incentive to apply for FDA approval for use in children because of the small market share compared to use in adults. For many drugs, children represent such a small proportion of the potential market that drug manufacturers do not see such testing as cost effective. Also, because there are ethical restrictions on the ability of children to give informed consent, there are increased governmental and institutional hurdles to approval of these clinical trials, as well as greater concerns about liability. Thus, most medicines, such as BMP, prescribed to children in the United States are done so in an "off-label" manner, with dosages "extrapolated" from adult data through body weight and body surface area calculations.

5. "Off-label" use for prescription drugs, biologics, and approved medical devices means any use that is not specified in the labeling approved by the FDA; it does not equate to illegal use, however. For cleared medical devices, "off-label" means any use that is not included in the cleared "indications for use."

6. Off-label use is not only legal and common, but it may also represent standard of care, particularly in pediatric medical practice. Off-label use arises through many pathways but usually entails the use of drugs for unapproved clinical indications (e.g., the antipsychotic agent quetiapine [Seroquel] prescribed for depression) or in unapproved subpopulations (e.g., paroxetine [Paxil] for depression in children). Off-label use may originate from a presumed drug class effect, extension to milder forms of an approved indication, extension to related conditions (e.g., the use of the anti-asthmatic montelukast [Singulair] for chronic obstructive pulmonary disease), expansion to distinct conditions sharing a physiological link (e.g., the use of the antidiabetic drug metformin to treat polycystic ovarian syndrome or sildenafil [Viagra] for pulmonary hypertension), or extension to conditions whose symptoms overlap with those of an approved indication.

7. The backlash against BMP was primarily due to the unholy union between surgeons and industry and not based on unequivocal scientific proof of harmful side effects; on the other hand, initial studies of beneficial and harmful effects of BMP utilizing the Yale Open Data Access (YODA) project were contradictory. One study concluded that rhBMP-2 has no proven clinical advantage over bone graft and may be associated with significant harm. ${ }^{3}$ Another study showed that at 24 months, rhBMP-2 increases fusion rates without evidence of increased long-term harm, such as cancer. ${ }^{6}$ It is hard to draw any further conclusions based on post hoc analyses.

8. Over the years, industry has faced increased scrutiny 
for BMP. In 2011, Dr. Eugene J. Carragee and several colleagues published an editorial in The Spine Journal ${ }^{2}$ revealing that a number of the researchers in the industry-sponsored studies received between $\$ 1$ million and \$23 million a year from industry in royalties and consulting fees.

9. Even before Dr. Carragee's article was published, the US Department of Justice was already investigating the industry. In a civil suit, the Department of Justice had accused a number of medical technology and services companies of paying kickbacks to doctors as an incentive to use BMP and other spinal products between 1998 and 2003. Some companies reportedly entered into sham consulting and royalty agreements and allegedly even paid for "lavish trips to desirable locations," according to court documents. In 2006, a company paid $\$ 40$ million to settle the civil suit. ${ }^{5}$

10. The FDA Safety Communication has the potential to alter the practices of many pediatric spine surgeons. It is conceivable that hospitals will find that the risks and liabilities of allowing their surgeons to continue to use BMP are too high and, consequently, ban its use. This would be unfortunate, however, as there are patient populations that undoubtedly would benefit from the use of BMP-e.g., very young children with a very limited amount of bone available for autograft harvest without undue morbidity.

11. The American Academy of Orthopedic Surgery ${ }^{4}$ and the Alliance of Specialty Medicine (of which the American Association of Neurological Surgeons is a member organization) $)^{1}$ released position statements, recapped and summarized below, to provide some degree of protection to their members regarding offlabel use of BMP.

In short, when using approved drugs, biologics, and devices in an off-label manner, the physician and surgeon have an obligatory responsibility to be well educated about the product, to use sound medical evidence, and to engage in a transparent discussion with the patient that puts the best interests of the patient above all else. Furthermore, documentation of this discussion in the medical record through an enhanced informed consent process provides assurance that an informative interaction between doctor and patient was undertaken. The physician must not only maintain records and track outcomes on the use and effects-both adverse and beneficial-of the product, but also know when an FDA investigational new drug or investigational device exemption may be needed.

FDA regulations prohibit pharmaceutical and device manufacturers from actively promoting and distributing written materials on off-label uses. Even so, open, honest, transparent, and nonmisleading scientific or medical published information on as-yet-unapproved new uses of drugs and devices may be of value to other health care professionals, which is the foremost objective of our study.

\section{References}

1. Alliance of Specialty Medicine: Physician-directed applications. A Position Statement of the Alliance of Specialty Medicine. AANS.org (http://www.aans.org/pdf/Legislative/ Alliance_Off-label\%20Statement.pdf) [Accessed March 16, 2015]

2. Carragee EJ, Ghanayem AJ, Weiner BK, Rothman DJ, Bono CM: A challenge to integrity in spine publications: years of living dangerously with the promotion of bone growth factors. Spine J 11:463-468, 2011

3. Fu R, Selph S, McDonagh M, Peterson K, Tiwari A, Chou R, et al: Effectiveness and harms of recombinant human bone morphogenetic protein-2 in spine fusion: a systematic review and meta-analysis. Ann Intern Med 158:890-902, 2013

4. Goodman SB, Friedman SJ, Cheng I, Greenwald AS, Buch BD: Off-label use of biologics and devices in orthopaedics. AAOS.org (http://www.aaos.org/news/aaosnow/oct14/ research4.asp) [Accessed March 16, 2015]

5. Infuse Bone Graft. Drugwatch.com (http://www.drugwatch. com/infuse/) [Accessed March 16, 2015]

6. Simmonds MC, Brown JV, Heirs MK, Higgins JP, Mannion RJ, Rodgers MA, et al: Safety and effectiveness of recombinant human bone morphogenetic protein-2 for spinal fusion: a meta-analysis of individual-participant data. Ann Intern Med 158:877-889, 2013

7. Stafford RS: Regulating off-label drug use-rethinking the role of the FDA. N Engl J Med 358:1427-1429, 2008

8. US Food and Drug Administration: Summary of Safety and Effectiveness Data. InFUSE ${ }^{\text {TM }}$ Bone Graft/LT_CAGE ${ }^{\text {TM }}$ Lumbar Tapered Fusion Device. (http://www.accessdata. fda.gov/cdrh_docs/pdf/P000058b.pdf) [Accessed March 16, 2015]

9. US Food and Drug Administration: Use of Bone Graft Substitutes Containing Recombinant Proteins or Synthetic Peptides in Patients under Age 18 - FDA Safety Communication. (http://www.fda.gov/MedicalDevices/Safety/Alerts andNotices/ucm430868.htm?source $=$ govdelivery\&utm medium=email\&utm_source=govdelivery) [Accessed March $16,2015]$

10. Veeravagu A, Cole TS, Jiang B, Ratliff JK, Gidwani RA: The use of bone morphogenetic protein in thoracolumbar spine procedures: analysis of the MarketScan longitudinal database. Spine J 14:2929-2937, 2014

11. Weiss KR: "To B(MP-2) or not to B(MP-2)" or "Much Ado About Nothing": are osteobiologics in tumor surgery worth the risks? Clin Cancer Res [epub ahead of print], 2015 